Meta

Journal des traducteurs

Translators' Journal

\title{
Interpreters and the Writing of History in China
}

\section{Rachel Lung}

Volume 54, numéro 2, juin 2009

URI : https://id.erudit.org/iderudit/037676ar

DOI : https://doi.org/10.7202/037676ar

Aller au sommaire du numéro

\section{Éditeur(s)}

Les Presses de l'Université de Montréal

\section{ISSN}

0026-0452 (imprimé)

1492-1421 (numérique)

Découvrir la revue

Citer cet article

Lung, R. (2009). Interpreters and the Writing of History in China. Meta, 54(2), 201-217. https://doi.org/10.7202/037676ar

\section{Résumé de l'article}

Le présent article soutient l'idée que les interprètes sont des personnages importants dans la consignation des évènements historiques. Des données puisées dans les textes historiques de la Chine ancienne ont été utilisées pour vérifier l'hypothèse selon laquelle des notes des interprètes auraient été consultées pendant la constitution des dossiers historiques. En montrant que la politique de la dynastie des Tang (618-907 ap. J.-C.) consistait à demander aux interprètes de mener des entretiens avec les envoyés étrangers et de remettre les comptes rendus au Bureau de l'historiographie, l'article fournit un cadre permettant de faire le lien entre les notes d'entretien des interprètes et la consignation historique en Chine. D'autres données ont été relevées à partir de l'histoire de la dynastie des Sui (581-618 ap. J.-C.), selon laquelle un compte rendu de la conversation entre l'empereur et un envoyé japonais, effectué par un interprète, a été directement adapté. Plus intéressants encore, les documents écrits et figurés sur des peuples étrangers produits vers la moitié du $\mathrm{VI}^{\mathrm{e}}$ siècle, pendant la dynastie des Liang (502-557 ap. J.-C.), ressemblaient beaucoup aux comptes rendus du Liangshu, c'est-à-dire l'histoire de la dynastie des Liang qui a été terminée au début du viI ${ }^{\mathrm{e}}$ siècle. Il existerait donc un rapport étroit entre les comptes rendus d'entretiens et les comptes rendus historiques sur les peuples étrangers en Chine. Par conséquent, il est fortement probable que les notes des interprètes, sous la forme de rapports, constituaient des sources importantes, sinon primordiales, pour la consignation des évènements historiques en Chine.
Ce document est protégé par la loi sur le droit d'auteur. L’utilisation des services d’Érudit (y compris la reproduction) est assujettie à sa politique d'utilisation que vous pouvez consulter en ligne.

https://apropos.erudit.org/fr/usagers/politique-dutilisation/ 


\title{
Interpreters and the Writing of History in China*:
}

\author{
RACHEL LUNG \\ Lingnan University, Lingnan, Hong Kong \\ wclung@ln.edu.hk
}

\begin{abstract}
RÉSUMÉ
Le présent article soutient l'idée que les interprètes sont des personnages importants dans la consignation des évènements historiques. Des données puisées dans les textes historiques de la Chine ancienne ont été utilisées pour vérifier l'hypothèse selon laquelle des notes des interprètes auraient été consultées pendant la constitution des dossiers historiques. En montrant que la politique de la dynastie des Tang (618-907 ap. J.-C.) consistait à demander aux interprètes de mener des entretiens avec les envoyés étrangers et de remettre les comptes rendus au Bureau de l'historiographie, l'article fournit un cadre permettant de faire le lien entre les notes d'entretien des interprètes et la consignation historique en Chine. D'autres données ont été relevées à partir de l'histoire de la dynastie des Sui (581-618 ap. J.-C.), selon laquelle un compte rendu de la conversation entre l'empereur et un envoyé japonais, effectué par un interprète, a été directement adapté. Plus intéressants encore, les documents écrits et figurés sur des peuples étrangers produits vers la moitié du vie siècle, pendant la dynastie des Liang (502-557 ap. J.-C.), ressemblaient beaucoup aux comptes rendus du Liangshu, c'est-à-dire l'histoire de la dynastie des Liang qui a été terminée au début du vII e siècle. Il existerait donc un rapport étroit entre les comptes rendus d'entretiens et les comptes rendus historiques sur les peuples étrangers en Chine. Par conséquent, il est fortement probable que les notes des interprètes, sous la forme de rapports, constituaient des sources importantes, sinon primordiales, pour la consignation des évènements historiques en Chine.
\end{abstract}

\begin{abstract}
This article argues that interpreters are crucial figures in the recording of history. Evidence taken from historical texts in ancient China is used to verify the claim that interpreters' notes might have been used as a reference in composing historical records. By documenting the Tang dynasty (AD 618-907) policy to have interpreters interview foreign envoys and submit the relevant accounts to the Bureau of Historiography, this article provides background for the link between interpreters' interview notes and history compilation in China. Evidence is further drawn from the history of the Sui dynasty (AD 581-618), whereby an interpreter's mediated account of the emperor's conversation with a Japanese envoy was directly adapted. Most interestingly, pictorial and written documents of foreign peoples made in the mid- $6^{\text {th }}$ century during the Liang dynasty (AD 502-557) were found to be very similar to the written accounts about these foreign peoples in Liangshu, the history of the Liang dynasty, completed in the early $7^{\text {th }}$ century. Apparently, there is a solid link between the interview accounts and historical accounts about foreign peoples in China. Thus, there is a strong possibility that interpreters' notes, in the form of reports, provide important, if not primary, sources for history compilation in China.
\end{abstract}

\section{MOTS-CLÉS/KEYWORDS}

interpreting history, Bureau of historiography, pictorial documents, written documents, interpreters' roles, ancient China

histoire de l'interprétation, Bureau de l'historiographie, documents écrits, documents figurés, rôle de l'interprète, Chine ancienne 


\section{Introduction}

In his book on the interpreting history of China, Li Nanqiu (2002) claims that interpreters' words might well have been used as part of historical records. His claim was then further refined by Lung and Li (2005) who analyzed texts in the historical records of different periods in China, where interpreting activities took place. They spell out possible ways in which interpreters' words can be traced in the historical record of inter-lingual encounters. Different scenarios are put forward concerning how interpreters possibly contributed to the making of historical records. These include: interpreters' notes being used as a reference in compiling historical events, interpreters being consulted for details after the inter-lingual exchanges, and historians referring to interpreters' renditions on the spot. In line with these arguments, no doubt, interpreters can be seen as being closely linked to the creation of historical records. Apparently, interpreters either actively or passively provided linguistic information to be used in recording historical encounters. Although the textual evidence provided by Lung and Li is valid and relevant to their arguments, the claims could be further verified.

In view of this, and as a continuous effort to document the importance of interpreters in the making and recording of history, I would like to locate evidence, again from historical texts in ancient China, to verify one of the claims made previously. Evidence, mostly from the Tang dynasty, will be put forward to lend support to the claim made by Lung and Li that interpreter's notes might have been used as references in the composition of historical records. This article is structured into three parts: first, background information about the Chinese world-view and an account of the central government framework, in which interactions with foreign envoys in China will be discussed; second, official interpreters' duties, which have a direct bearing on the compilation of historical records; third, examples of the probable use of interpreters' notes in compiling historical records of Liang and Sui dynasties (both completed in $\mathrm{AD}$ 636) in Tang China.

\section{The Chinese World Order}

The specific way which Chinese people view themselves and the "others" was rooted in their culture as early as in the Zhou (1100 BC-771 BC) dynasty, when the emperor of China was considered the Son of Heaven (Tianzi 天子) ruling All-under-Heaven (Tianxia天下). Ever since the establishment of the Tang Empire, China saw itself as the epitome of world civilization. Sustained by remarkable military victories in Central Asia and East Asia, and unprecedented territorial expansion which went beyond the traditional confines of China proper, Emperor Taizong (reigned during AD 627-650) was honored by foreign rulers in Central Asia, East Asia, and countries along the frontier as the "Heavenly qaghan," who commanded his government to protect and acculturate these tributary or satellite states in a Confucian fatherly or brotherly manner. The tribute system was then developed "to help consolidate the Chinese belief in the inevitability of her ideal world order" (Pan 1997: 25).

In ancient times, different terms were used to refer to non-Chinese: most notably, $\mathrm{Hu}$ (胡) for China's northern frontier neighbors, Yi (夷) for uncivilized people from the south-western border, ${ }^{1}$ and Man (蠻) for barbarians from the southern frontier. 
But in the cosmopolitan Tang dynasty, "Hu" broadly used to refer to "Westerners, such as Iranians, Indians, Arabs, and Romans" (Schafer 1963: 4). Samuel Adshead gives a detailed account of Tang China's pre-eminence in Central Asia and Western Eurasia when he says

Tang's cosmopolitanism [was featured] in the intense interest in things and people foreign exhibited by the court at Changan, which, along with the attractions of China, brought an unprecedented influx of non-Chinese to the Middle Kingdom, both from other parts of East Asia and from Western Eurasia. (Adshead 2004: xiii)

Besides, Chang'an (near the present-day city of Xi'an), the capital at the time, had almost two million taxable residents (Schafer 1963: 5-7) who were primarily men from the Northern and Western tribes, such as Turks, Uighurs, Kirghizes, Khitans, Tibetans, Tocharians, and Sogdians. The story of the Chinese frontier was naturally also a story of differences, presumably in ways of living, other than in languages or culture: an intensive farming practice supplemented by animal husbandry in China, as opposed to the extensive nomadic pastoral lifestyle of the $\mathrm{Hu}$, supplemented by hunting, fishing and rudimentary agriculture. Apparently, the stable and settled lifestyle of China was tempting to the nomadic $\mathrm{Hu}$, and in response to the friendly approach of Tang China to non-Chinese, a large number of non-Chinese settled in Chinese territory. ${ }^{2}$ With millions of foreigners coming in and out, or even settling in China, the burden, in terms of the workload for the central administration, was understandably enormous.

\section{Central Government Offices Dealing with Foreigners}

In line with the policy of peaceful co-existence with foreigners, an elaborate central administrative framework where interpreters were part of the establishment, was institutionalized to cater to the crucial need to deal with the non-Chinese in ancient China. The most important office in handling foreigners (officially speaking) in China was the Court of Diplomatic Reception (also known as honglu si [䲨臚寺], ${ }^{3}$ hereafter, “the Court"), a part of the Ministry of Rites (libu 禮部) in the Department of State Affairs (shangshu sheng 尚書省). Its role was to receive and welcome tributary envoys, and to ensure their pleasant stay in China.

The Court, headed by the Chamberlain (qing 卿), coordinated all foreignerrelated activities with relevant branches in the central government, with the help of around two hundred official assistants of various ranks in the Court (Yuan and Pan 1997: 506). The position of the Chamberlain, as a third-rank official, was usually filled by someone with experience in handling foreigners and frontier military activities, ${ }^{4}$ often of naturalized Chinese background. His major duties were to keep track and take care of activities of the incoming envoys as well as making diplomatic trips to foreign states in order to maintain friendly ties and collect strategic information for China. The Court normally recruited twenty interpreters (yiyu ren 譯語人) or translators (Yuan and Pan 1997: 42), who ranked no higher than the seventh rank in the traditional nine-tiered official hierarchy in China, where the first rank was the most senior of all. The fact that interpreters took up almost one-tenth of the Court's establishment indicates their importance to the operation of the Court. ${ }^{5}$ In spite of their junior status, these interpreters' actual contributions to the Court's work must have been rather indispensable. 


\title{
4. Roles of Interpreters in the Court of Diplomatic Reception
}

The Court bore a wide range of responsibilities. ${ }^{6}$ For the purpose of this article, only the specific tasks of the Court's interpreters which were related to the recording of official history will be discussed in detail. The link between interpreters' work in the Court and the history compilation in China is particularly relevant. In the Chinese historiographical tradition, a standard history is normally composed of the basic annals and biographies (which include entries on, among others, memoirs of various foreign peoples). The sources on which standard records of historical events were based, however, varied across dynasties. The more common sources include Court Diaries, Records of Administrative Affairs and Veritable Records. ${ }^{7}$ Subsequent to the reorganization of the Bureau of Historiography in Tang China (see Xie 1995: 70 for details), various government agencies and ministries were legally required to collect specific types of information and documents and submit them to the Bureau on a regular basis for history compilation (see Denis Twitchett 1992: 27-29.). One of the official sources of Tang's history, Tang Huiyao [Collections of Important Documents of the Tang] notes that

\begin{abstract}
Departments are required to report the following to the Bureau of Historiography: Appearance at court of tribute-bearing missions from foreign countries. Whenever such a foreign mission arrives, the Court of Diplomatic Reception should examine them on the natural conditions and customs of their country, on their dress, and the products brought as tribute, and on the distance and route by which they have come. These facts are to be reported together with the names of their leaders...All the above matters should be investigated and reported to the Bureau of Historiography as they occur by the responsible authority specified in the appropriate section. (Tang Huiyao 63: 606-802-3; Denis Twitchett's translation, 1992: 27, 29. The original Chinese text is attached as Appendix 1.)
\end{abstract}

This document suggests that the Court was legally required to interview the visiting envoys and submit relevant reports to the Bureau of Historiography. Also, it seems that the Court was given a standard list of questions (quite uniformly documented in various historical sources, such as Xin Tangshu [New History of the Tang], Jiu Tangshu [Old History of the Tang], Zizi Tongjian [Comprehensive Mirror for Aid in Government] and Tang Huiyao etc.) for the interviews. Since there was no mention of interpreters in the above quotation, we cannot entirely rule out the possibility of multilingual officials in the Court who could handle the interviews quite independently without interpreters. However, given the fact that a Court of two hundred staff requires twenty interpreters, which is an extremely high ratio, the logical conclusion would be that these interviews were most likely conducted with the help of interpreters. In the discussion that follows, we will also see that officials from other departments were sometimes present in the interview. Either way, interpreters would obviously be indispensable for everyone present to be informed about and be understood in the exchange that occurred.

Since presumably the interpreters' (or the other Court officials') reports were compiled based on notes taken during the interviews before submitting to the Bureau of Historiography, these notes or reports would then become important sources of reference for historians in compiling standard historical event records of the time. Admittedly, we do not have exact information as to the way the reports from the 
various departments were disposed of in the process of history compilation. The compilers and assistants in the Bureau of Historiography might have adopted them in full, or alternatively, they might have exercised their professional history writing skills to verify, edit, re-edit, and polish those reports before inserting them in the biographies of the standard history. It is, however, quite reasonable to assume that these reports, composed with the help of, if not by, interpreters, provided useful sources for history compilation. After all, the report from interviewing foreign envoys could be the only source of direct information about these exotic countries, which had diplomatic ties with China at specific time.

The claim made by Lung and Li (2005) that interpreters' notes could have been used as a reference for historians, is therefore initially validated. However, the fact that it was the standard official practice in Tang China for the Court to keep and submit written records about what happened at interviews with foreign envoys proves only half of the argument, namely that interpreters were indirectly involved in the compilation of histories in China. In order to prove that interpreter's notes were actually used by historians in China, we need to establish a concrete link between information provided by the Court's interpreters and the actual compilation of historical records.

\section{Use of Interpreters' Notes as a Source for Compiling Histories}

Interpreters' task in relation to the interviewing of foreign envoys was also documented in Tang Liudian Quanyi [A Complete Translation of Compendium of Administrative Law of the Six Divisions of the Bureaucracy of Great Tang]. It states:

[...] whenever foreign envoys arrived at the capital, the Court of Diplomatic Reception was required to make enquiries about the geographical conditions of their countries and their customs. Afterwards, maps of these foreign places in their geographical relation to China and pictures of these envoys, were drawn. Copies of these were sent to the Secretariat (to which the Bureau of Historiography was subordinate), while the originals were kept in the Court. (Tang Liudian Quanyi 5: 122; my translation; the Chinese text is attached as Appendix 2.)

Maps of foreign countries in relation to China and drawings of foreign peoples were important documents for Tang China. These documents appear to be essential archives to the government. The division of operation in the Department of Arms, for example, was chiefly responsible for making maps of the neighboring countries and the landscapes in between. The visit of foreign envoys therefore represented essential channels for the government to update their information. Edward Schafer remarks that

[t]his important office [honglu], quite aside from its basic responsibilities, served also as a clearinghouse of information about foreign countries, which was of great value to the nation, especially to the strategists of the army. A special agent of the Department of Arms was sent to interview the envoy immediately upon his arrival. He was interrogated about the geography and customs of his native country, and a map was constructed from the information supplied. (Schafer 1963: 26-7)

The interview as mentioned in the above quotation could be the same interview as the one conducted in the Court, in which case it can be safely assumed that the 
interview panel included officials from outside the Court. We do not know, however, if the special agent from the Department of Arms was an active interviewer or a passive participant in the interview. But his presence certainly calls for interpreting service in the Court's interview with foreign envoys. According to Pan Yihong, the Chinese started to show great interest in collecting information about foreign countries in as early as the Han dynasty (206 BC-AD 8). Such information, collected from different sources, Pan (1997: 82-93) says, formed the basis not just for formulating foreign policies, but also for compiling accounts of foreigners in the standard histories from Shiji [Records of the Grand Historian] onwards. ${ }^{8}$ Since the Court of Diplomatic Reception, with a pool of twenty interpreters and other officials, was the only major department which dealt with foreign envoys in China, the office became an essential point of contact for foreign countries. With its direct access to the envoys through interpreters, the office was the best platform to collect and accumulate information about foreign countries. According to $\mathrm{Li} \mathrm{Hu}$,

[...] the Court not only has to report information about foreign countries to the central government, but also has to accumulate the collected information for history compilation and consultation. (Li 1998: 337)

Li's claim that the Court had a part to play in "history compilation" is not without ground. After the Western regions were brought under the control of Tang China in the reign of Emperor Gaozong (AD 650-684), the imperial court sent special missions (obviously with interpreters included) to these regions to collect information on local customs and products, which eventually found its way into Xiyü Guozhi (西域國志) [Accounts of the States of the Western Regions], with maps and other illustrations compiled by the Bureau of Historiography. However, Liu Boqi notes that "illustrated publications of foreign countries, such as Xiyü Guozhi, compiled by the Court's Chamberlain, mostly focus on the foreign peoples, their features, dress codes and customs" (Liu 1974: 272). ${ }^{9}$ The fact that both the Bureau of Historiography and the Court's Chamberlain were mentioned in standard histories as the compiler of the book suggests that they could have worked closely in publications about foreign countries.

Besides, Jia Dan (AD 730-805), once the Chamberlain of the Court, published several geographical works about China's neighbors. ${ }^{10}$ According to his biography, ${ }^{11}$ his experience as the Chamberlain gave him direct access to information from either the in-coming envoys or the returning Chinese envoys. Schafer even claims that Jia Dan's remarkable knowledge of world geography was derived "from personal interviews with the visiting envoys" (1963: 27).

Information from foreign envoys may not have been directly useful for political decisions, but it was certainly given great importance by the Chinese court. For example, mediated (by interpreters, probably) exchanges between the emperor and foreign envoys were directly adapted in Suishu, an official history of the Sui dynasty. Since terms such as "the Court of Diplomatic Reception" and its "chamberlain" were mentioned several times in Suishu (p.1827, p.1876), it is likely that the Court, in operation during Sui, would also be equipped with interpreters. For example, Mohe (靺鞨) (a tribe settled in Northern Korea) envoys were sent to pay tribute to Emperor Wen of Sui around AD 583. 
The emperor told the envoys [of Mohe], "I heard that people in your country are mostly brave and quick. I am so glad to have met you. You are like my sons and you should just respect me as if I were your father." One of the envoys then replied, "Your servants [We] are from a remote area of a distant land. Since we heard that there is a holy person in this country, we decided to pay our tribute. Your subordinates were so overwhelmed in seeing your saintly face and in receiving generous gifts from you that [we] are willing to be your servants forever." (Suishu 81: 1822 [Eastern Barbarians], my translation. The Chinese text is attached as Appendix 3.)

The discourse feature of Suishu is mostly descriptive paragraphs with occasional insertion of memorials from major officials. Unlike Shiji, dialogues are not often found in Suishu. Since this part of the Sui history was in the form of dialogues, which involve foreign envoys, the most likely scenario is that the interpreter's mediated accounts on the occasion might have been simply recorded and found their ways directly into Suishu. The interpreter's role, as suggested in this example, is again inseparable from the recording of history in China. Besides, when the Yamato (known as Japan since AD 700) envoy arrived at the Sui court in AD 600, Emperor Wen asked the official-in-charge to inquire after the customs of Japan, and the envoy's detailed answers were again incorporated into Suishu.

The emperor asked the official-in-charge to inquire about the customs [of Yamato state]. The envoy said, "our sovereign (Suiko Tenno, the first female emperor in Japanese history) regarded Heaven as her elder brother and the sun as her younger brother. She would sit with legs crossed while listening to the government affairs before dawn and stop working once the sun rises." (Suishu 81: 1826 [Eastern Barbarians], my translation. The Chinese text is attached as Appendix 4.)

The official-in-charge, here referred to, was most likely an official or interpreter in the Court of Diplomatic Reception, which was known as the Grand Honglu Office in the Sui dynasty (Li 1998). Whereas the question put to the envoy was an indirect description, the envoy's answer was recorded quite elaborately in Suishu. Like previous dynasties, the Sui emperors were keen on having foreign envoys in China. Emperor Yang, in particular, considered it a sign of political stability and prestige and asked his court officials to visit foreign countries to facilitate tribute-paying missions to China. Pei Ju, for example, was frequently sent to the western frontier to develop diplomatic ties and collect information about the west for the emperor. In the biography of Pei Ju in Suishu, the way he came up with the publication of Xiyu Tuji 西域 圖記 [An Illustrated Account of the Western Region] was documented.

$[\mathrm{He}]$ located books, accounts and interviewed foreigners in the frontier markets. When he came to curious matters, he would ask for details from other [foreigners]. He would draw pictures immediately to make records of the dress codes, demeanor, and features of their kings and civilians. (Suishu 81: 1579 [Eastern Barbarians], my translation. The Chinese text is attached as Appendix 5.)

Although we do not have any detailed accounts of the Sui policy to interview foreign envoys and draw their pictures as part of the government archives, the biography of Pei Ju (AD 547-627), a prominent figure in Emperor Yang's reign, did prove the existence of similar practice in the Sui dynasty.

As a measure to secure stable political transition, it was common for imperial China to continue good practices of the previous dynasties. During the Tang era, continuing a tradition that must have gone back to much earlier times (see discussion 
below), various government agencies that dealt with foreign envoys were required to make regular reports to the Bureau of Historiography. The Court of Diplomatic Reception, for instance, regularly questioned foreign envoys about their countries; sometimes at an imperial audience, the emperor himself would put questions to them (see Lung and Li [2005] for actual instances), again following the checklist of questions along the lines of local customs, products, geography, and the like. Although it is not entirely clear how binding the rules for reporting information were, the accounts of foreign states and peoples in the standard histories, presumably partly based on such information, show that there were indeed such reports produced for - and used, perhaps selectively, by - the historiographers (Pan 1997). When Kirghiz (present-day Kirghizstan or Kyrgyzstan) envoys arrived at the Tang court in AD 843, for example, interpreters were asked to interview them about the geography and customs of their nation. Afterwards, a painting of these envoys was drawn, and an account of the Kirghiz nation came to be written down (not extant). The crucial document that points to the presence and work of an interpreter in this particular interview with Kirghiz envoys was documented.

During the middle of the Huichang reign period, a Kirghiz envoy was killed on his way to paying tribute to China [by a Uighur fugitive]. Later, Zhu-wu Alp Sol was sent with a letter [from the Kirghiz ruler] to explain the mishap. Zhu-wu Alp Sol spent three years on the road before he arrived at the Tang capital. At the audience with Emperor Wuzong, he was imperially arranged to line up in front of the envoy of Parhae. The emperor was delighted that the Kirghiz envoys came a long way from their remote country to pay tribute to him. He then asked the chief minister [Li Deyu] to meet the Kirghiz envoys in the Court and instructed the interpreter to inquire about the [Kirghiz] landscapes and customs. It is also an imperial order that an illustrated publication [about the tribute mission of the Kirghiz envoy] should be produced based on the information collected by the Court. (Xin Tangshu 217: 6150, my translation; the Chinese text is attached as Appendix 6).

The above quotation confirms that an interpreter was assigned to inquire about the landscapes and customs of the Kirghiz people during the interview in the Court. It also ascertains that the presence of the interpreter and his enquiry of foreign envoys in the Court's interview seem to be a regular practice. It is quite likely that the interpreter could be making the record while he inquired the envoys and mediated exchanges for Chinese officials attending the interview. It should also be noted that interpreters in the Court, with their knowledge in foreign languages, were actually entrusted with the task to collect information about foreign countries by direct enquiry, not just as mediators of interpreting events.

\section{Interviews with Foreign Envoys}

Although different historical sources so far describe the official procedures of interviewing foreign envoys adopted by the Court, there had been little discussion about the exact nature of the interview, until I located a written memorial from Li Deyu (AD 787-850), the Chief Minister of Emperor Wuzong (reigned during AD 841-847) in the Tang dynasty and a relevant document from Tang Huiyao. When the Kirghiz dispatched their second batch of envoys (the first being sent in AD 842) to the Chinese court during the reign period of Huichang of Emperor Wuzong around AD 843, an 
interview, as a rule, was conducted with the Kirghiz envoys and a portrait of the envoys drawn. Afterwards, Li Deyu submitted a memorial to the emperor. This document disclosed crucial details as to the way in which the interview with the envoys was carried out. The original memorial in classical Chinese is attached as Appendix 7, while the English translation is as follows:

\section{A Memorial Offering an Account and a Painting of the Kirghiz Tribute Mission}

On the twenty-first day, I memorialized in person in the Yanying Hall that Lü Shu and others had been imperially authorized to inquire about the customs in the Kirghiz capital and to compile this [information] into one zhuan [memoir]. Now it has been completed; it seems to have been prepared carefully. I humbly observed that at the beginning of the Zhenguan reign period, because all the four [kinds of] barbarians came to court, Taizong ordered Yan Liben to sketch the clothing and appearance of each of them, making a painting of them offering tribute. [Thus,] I respectfully ordered a painter to make a sketch of the appearance of Zhu-wu Alp Sol [Kirghiz envoy] and the others, to be placed at the beginning of the zhuan. At the same time Your servant, not considering his inferior ability, wrote a preface to the account (Translated in Suprunenko 1963, in Michael Drompp [2005: 293]).

Basically, the memorial was submitted alongside the account of the Kirghiz people and the accompanying painting. The purpose of this memorial was to inform the emperor of the completion of the account and the painting. It also made a pointed reference to Emperor Taizong's success in drawing foreigners to his court in the past. Besides, Li Deyu had also written a preface to the account of the Kirghizes to commemorate the historical event. Obviously, the systematic collection of information about foreign envoys and the paintings of these foreigners and their geographical landscapes continued, perhaps more vigorously, in the late Tang dynasty.

According to Tang Huiyao, Zhu-wu Alp Sol and six fellow envoys from Kirghiz brought two horses for the Chinese emperor and hoped that the Tang emperor could award the Kirghiz king a title (100: 1785). As instructed by Emperor Wuzong, the envoys were interviewed at the Court of Diplomatic Reception about the geography and customs of their nation. It seemed that a group of seven Kirghiz officials was interviewed by a number of Chinese officials, some from the Court, with at least an interpreter and a painter for the event, while others from the Department of Arms must have been present at the interview as well.

Lü Shu, a fourth-ranking official mentioned above in the text, was then the "Sub-director of the Department of the Imperial Library,"12 who "wrote books for the imperial court" (Fu and Zhou 2000: 384; Xie 1995: 211). ${ }^{13}$ Interestingly, an examination of Li Deyu's preface to the memoir of the Kirghiz reveals more about this particular interview. He says

...[T]herefore, the king of Kirghiz sent a letter and two quality horses with Zhu-wu Alp Sol. Gujin Junguo Xiandao Siyi Shu [Discussion of the Four Kinds of Barbarians in China, Past and Present], written by the ex-Chief-Minister, Jia Dan, has actually informed us that the Kirghiz was originally called the state of Jiankun. Jia Dan's works have been useful references for the past and present. Thus, I asked Wei Zongqing, an advisor to a prince, and Lü Shu, the Sub-director of the Department of the Imperial Library, to visit the Court [where the Kirghiz envoys were] and try to give an authentic and detailed account of the differences and similarities between the Kirghiz people and the Chinese. Hopefully, we would then get a better understanding of the Kirghiz people and their geographical conditions. Finally, I took the liberty of writing a preface 
to the exotic account of the Kirghiz as recorded by Wei Zongqing and Lü Shu to accompany the painting of the envoys. (Fu and Zhou 2000: 20-22, my translation; the Chinese original is attached as Appendix 8)

From the preface of Li Deyu, we know that Wei Zongqing was also asked to attend the interview with the Kirghiz envoys. But it seems that the role of both Wei Zongqing and Lü Shu served more as observer or note-taker (through the interpreter's mediation) than active interviewers on the occasion, since these two officials belonged to neither the Court of Diplomatic Reception nor the Department of Arms. In this connection, it is reasonable to assume that, for some interviews with foreign envoys at least, officials from other departments were present in different capacities as well. It is possible that some interviews might have been more elaborate than others, depending on the agenda behind the interview, which reflected diplomatic, strategic and documentary needs. In this particular example, apparently, the two officials were summoned by the chief minister to gather information from the interview with the Kirghiz envoys to compile a memoir, which appears to be a task of some priority for the imperial court.

Although this memoir is no longer extant, its title, (紇戛斯朝貢圖傳) [An Illustrated Transmittal on the Tribute Offered at the Levee by the Kirghiz], was documented in other books (Schafer 1963: 273; Xie 1995: 211). Apparently this memoir had ten chapters, and Li Deyu's preface to it was noted as a single chapter (Light 2001: 495). It is quite possible that Lü Shu's publication was a product of the interview with the Kirghiz envoys. Presumably, notes or reports of the (interpreter-mediated) Kirghiz interview as compiled provided highly relevant information in the writing of this book.

Considering the fact that interpreters mediating in the interview with envoys were affiliated to the Court, and that they were required to collect information about foreign countries for the Bureau of Historiography, it seems logical to assume that, at the time, as a common practice, they might also have coordinated those interviews - from the actual interpreting to the putting down of relevant information in a written report - to be submitted along with the painting to the Bureau on behalf of the Court. In this light, interpreters' notes were probably essential sources for the compilation of certain historical records concerning foreigners in China.

\section{Links between Interview Reports and Historical Records}

Pictorial collection of visiting envoys and written accounts of their countries appear to be a common theme for paintings commissioned by the imperial court. Paintings titled Zhigong Tu (職貢圖) (Tribute-paying Picture) were found in different reigns of the Liang and Tang dynasties.

Figure 1, painted in the mid- $6^{\text {th }}$ century, is part of the entire Zhigong Tu, which contains the portraits of two foreign envoys, with a written account about each of their countries. The painting, widely believed to be an imitation made in the Northern Song dynasty (AD 960-1127), was originally made by Emperor Yuan (Xiao Yi, reigned during AD 552-555) during the Liang dynasty (Jin 2004: 217). ${ }^{14}$ Assuming that these portraits and associated accounts were produced during or after interviews with the foreign envoys in the Court of Diplomatic Reception, ${ }^{15}$ this textual and pictorial evidence could be related to the use of the interview data and the report 


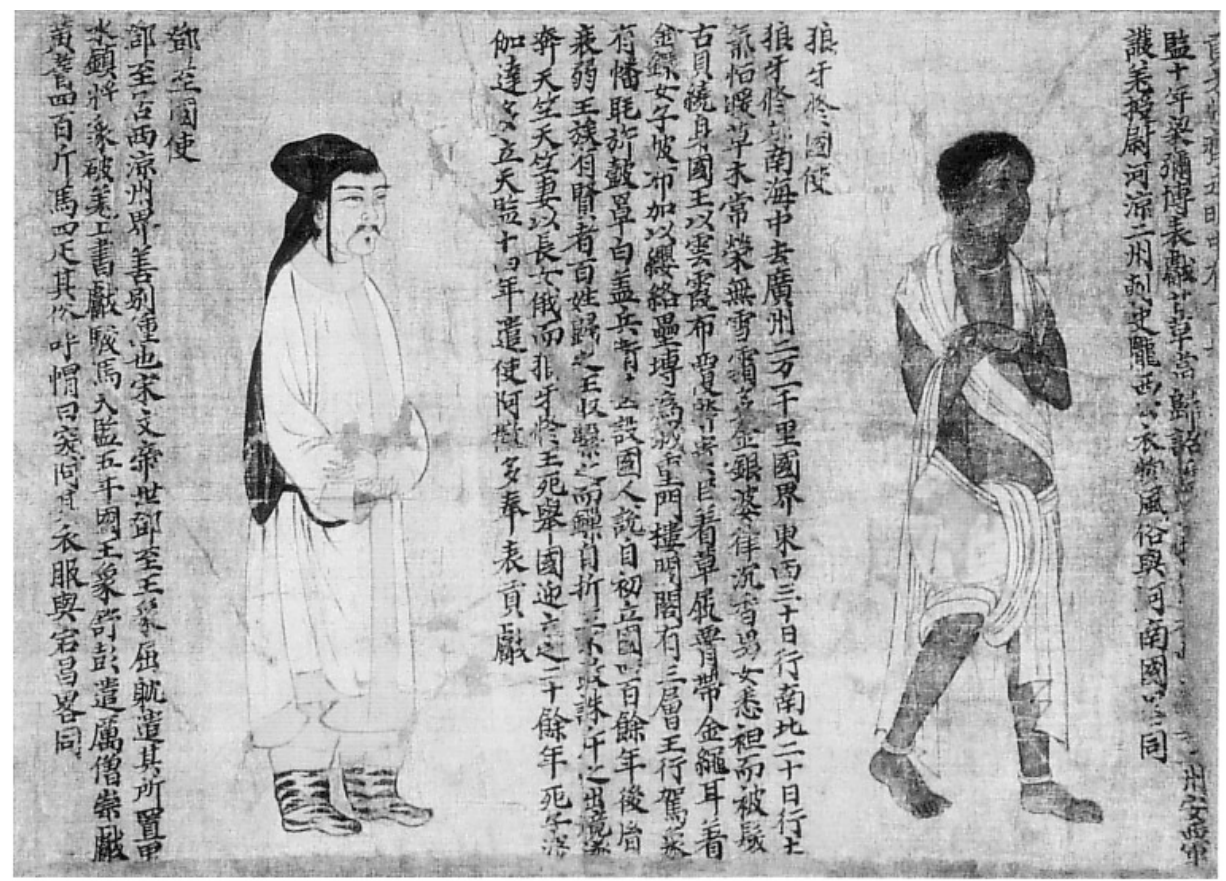

submitted afterwards. ${ }^{16}$ While we do not have extensive historical records about portraits drawn during interviews with foreign envoys in the Liang dynasty, there is evidence from Liangshu which points to the similar practice of envoys being interviewed in the Court of Diplomatic Reception,

[These foreign countries] are all listed as our tributary states. Tribute-paying foreign envoys, dressed in exotic and unfamiliar clothes, gathered at the Court to be questioned. It is a blessing for countries close by and faraway. (Liangshu 5: 130 [Emperor Yuan], my translation; the Chinese text is attached as Appendix 9).

Figure 1 provides solid evidence of the practice during the Liang dynasty to draw portraits of foreign envoys and have information about their landscapes and customs recorded next to their portraits. These written records might have been made during their interviews at the Court as suggested by the above quotation of Liangshu. As to the entire Zhigong Tu, there are still controversies over the actual number of envoys drawn in the original work. Although there are twelve full-size portraits of foreign envoys in the existing exhibit in the National History Museum of Beijing, I located texts about thirteen countries (not twelve) in this painting, with an account of about 60 to 250 words describing each of the countries, placed against the portrait of the envoy concerned. ${ }^{17}$ This suggests that at least one portrait is missing in the existing painting. The countries documented in this painting, in sequence, are: Hephthalites (present-day Afganistan), Persia (present-day Iran), Paekche (North Korea), Guizi, Yamato, Dangchang (present-day Gansu, China), Langya Xiu, Dengzhi (present-day Sichuan, China), Zhouguke, Kebatan, Humidan, Baiti and Mo. 
Three important observations should be noted in connection with this painting. First, the content and profile of the written accounts, short and long alike, interestingly, tally with the standard lists of questions asked during interviews with foreign envoys in the Court during the Tang dynasty. The textual information consists of the name of the country, its geographical location in relation to China, its climate, products, customs, its history and political ties with China, its present king, and the tributes being brought along. It is quite possible that the "report" submitted to the Bureau of Historiography (or its counterpart during the Liang dynasty) actually used a similar format to the one shown in Figure $1 .{ }^{18}$ If this is the case, it can be deducted that Tang China actually inherited the practice and tradition regarding the collection of information about foreign countries from previous dynasties such as the Liang and the Sui at least. Ironically though, it is the detailed records in Liangshu composed in Tang history that give us hints about what the background of this painting, made in Liang, is all about.

Second, since the portrait was drawn by a Liang emperor, there must have been interaction between the emperor and selective envoys, probably inside the imperial palace. Just as the accounts of these thirteen countries vary in length, the Chinese court might have valued some countries more than the others with due consideration of their strength and strategic importance in the region. However, we do not know how involved the emperor was in questioning the envoys. But the written accounts in the painting were likely to have been provided by the interpreter(s) or associated official(s) who mediated in the inter-lingual encounter and then wrote the accounts.

Third, the written accounts in the painting (made in mid- $6^{\text {th }}$ century) were found to be virtually identical to the ones found in the memoir of barbarians in Liangshu (completed in the early $7^{\text {th }}$ century). For instance, the longer account in the middle of the painting is a description of the country called Langya Xiu 狼牙修. This account was found almost verbatim in the account of Langya Xiu in Liangshu (AD 636: 795). The text in Liangshu, however, was punctuated and fine-tuned stylistically, perhaps by the compilers, for better readability. Besides the addition of the full text of the state letter from Langya Xiu at the end of the account, textual changes introduced, as can be seen when compared to the account on the painting, were minimal. As to the shorter account (on the left of the painting) of the country called Dengzhi 鄧至, it was largely used in the account of Dengzhi in Liangshu (AD 636: 815-6), with a short insertion of an update on historical events. The insertion and stylistic enhancement in the historical account, again, are likely to be the work of the compilers of Liangshu. The incomplete text to the right of the Langya Xiu envoy can be traced as making up part of the textual account of Dangchang 宕昌 in Liangshu (AD 636: 815), with a high level of similarity towards the end of the text in question.

Notwithstanding the incomplete state of the painting, its textual records must have once facilitated the successful compilation of the history of Liang in AD 636 before it was damaged, probably at a later time during the Tang dynasty. In a way, reference to Liangshu complements our understanding of the incomplete written records on the painting, although ironically, the compilation of the part on barbarians in Liangshu, was probably based on interpreters' reports of interviews with these envoys. In order to conclude the degree of resemblance between the thirteen texts on the painting and the corresponding accounts in Liangshu, I have conducted a tentative textual analysis and come up with the following statistics. 
TABLE 1

Degree of resemblance between Zhigong Tu and the memoirs for barbarians in Liangshu

\begin{tabular}{|l|l|c|l|}
\hline & Name of Country & $\begin{array}{c}\text { Degree of } \\
\text { Resemblance }\end{array}$ & Areas and Reasons for Discrepancies \\
\hline 1 & Hephthalites 滑 & $95 \%$ & Paragraphs rearranged in Liangshu \\
\hline 2 & Persia 波斯 & $85 \%$ & $\begin{array}{l}\text { Contents and wordings largely identical, } \\
\text { with some parts on the painting vaguely } \\
\text { legible }\end{array}$ \\
\hline 3 & Paekche 百濟 & $80 \%$ & $\begin{array}{l}\text { Incomplete beginning and ending on the } \\
\text { painting }\end{array}$ \\
\hline 4 & Guizi 龜茲 & $50 \%$ & One-quarter not legible on painting \\
\hline 5 & Yamato 倭 & $25 \%$ & Incomplete, but wordings highly identical \\
\hline 6 & Dangchang 宕昌 & $60 \%$ & Incomplete, but wordings highly identical \\
\hline 7 & Langya Xiu 狼牙修 & $85 \%$ & $\begin{array}{l}\text { Content and wordings highly similar, with } \\
\text { stylistic changes introduced in Liangshu, } \\
\text { state letter included in Liangshu }\end{array}$ \\
\hline 8 & Dengzhi 鄧至 & $90 \%$ & $\begin{array}{l}\text { Content and wordings highly similar, with } \\
\text { stylistic changes introduced in Liangshu }\end{array}$ \\
\hline 9 & Zhouguke 周古柯 & $20 \%$ & Shortened text in Liangshu \\
\hline 10 & Kebatan 柯跋檀 & $30 \%$ & Shortened text in Liangshu \\
\hline 11 & Humidan 胡蜜丹 & $30 \%$ & Shortened text in Liangshu \\
\hline 12 & Baiti 白題 & $80 \%$ & Two typo errors in Liangshu \\
\hline 13 & Mo 末 & $75 \%$ & The other 25\% missing on the painting \\
\hline & & & \\
\hline
\end{tabular}

Inevitably, the degree of resemblance in terms of percentage, as presented here, is basically impressionistic rather than totally objective. The statistics, however, do serve to reflect that there is a significant link between the textual information on the Zhigong Tu and the corresponding historical texts found in the accounts of barbarians in Liangshu. Since Yao Cha (AD 533-606), one of the compilers of Liangshu, served as the official historiographer in the Liang dynasty, he certainly was involved in the collection of useful information for potential history compilation. It is not surprising that the Zhigong Tu turned out to be an indispensable source for Tang China's understanding of barbarian states which sent envoys to China during the Liang dynasty. Eventually, when Yao Cha and his son, Yao Silian, were entrusted with the task to compile the history of Liang in the Tang dynasty, the Zhigong Tu, which contains elaborate details of customs and histories of barbarian states, became an important reference source. It is essential to note that the reasons for the existing discrepancies between the two texts are mostly due to missing information resulting from the damage on the painting and stylistic changes introduced possibly in the process of editing and history compilation. Besides these differences, the two texts are mostly intrinsically identical in terms of content and wording. These similarities could not have been accidental; they are borne out of the fact that interpreters' reports of the interviews with these foreign envoys were taken as essential references in history compilation about these foreign states.

In other words, the painting and its textual account completed (probably with the help of interpreters) did provide the direct source materials for compiling the history of the Liang. In this regard, inarguably, there seems to be a direct and solid link between the substance of the interviews and the historical accounts about foreign 
peoples in China. Notwithstanding the scanty evidence found so far, the possibility that interpreters' notes, in the form of reports sent to the Bureau of Historiography, provided important, if not primary, source materials for history compilation in China, cannot be ruled out.

\section{Conclusions}

The cosmopolitanism of Tang China attracted an unprecedented mix of foreigners to China, and they had each their own political, commercial, or religious agenda. Cross-cultural and cross-linguistic interaction thus gave rise to greater use of interpreting services in ancient China. For interpreting researchers, the history of Tang China surely provides an ideal platform to study the roles of interpreters in East-West exchanges. Most naturally, therefore, it is within this historical time frame that valuable information about Chinese interpreting can be located.

Edwin Pulleyblank says, "it is a truism that China possesses a wealth of historical writing unequalled by any other country before modern times" (2001: 135). This article identifies relevant historical documents, which have an important bearing on the study of the interpreting history of Tang China. By revealing the Tang practice to interview foreign envoys in the Court, locating textual and pictorial evidence about these envoys and their countries, and verifying the actual adoption of some materials (collected based on interviews) in its archival accounts of foreign peoples, this article hopes to draw logical links between the interpreters' written accounts as derived from the interviews and the publication of various official documents on foreign peoples and landscapes on the one hand, and between these accounts and the compilation of memoirs for foreign countries on the other. The process whereby interpreters' notes might have served as important references in the compilation of histories on cultural and political exchanges for China, as well as the nature of interviews with foreign envoys, were also analyzed through a close study of the texts. In this way, the claim of Lung and $\mathrm{Li}$ (2005) made earlier, regarding interpreters' role in the provision of linguistic information for history compilation in China, can be verified and substantiated.

It must be admitted that the present article only manages to explore an extremely limited area on interpreting history in China. However, the experience of researching on this specific issue of interpreting history reveals to me the astonishing potential of using historical records and documents in expanding our knowledge in this underexplored area. Historical documents such as memoirs, paintings, memorials, imperial edicts, standard histories, and time-honored publications of various sorts, when examined thoroughly, are highly inspiring. The unknown elements in interpreting history will be further unveiled to us this way. These historical records will surely continue to have a lot to offer to the historians of interpreting in China.

\section{ACKNOWLEDGEMENTS}

* This research has benefited from financial support (DA04A7) from the Research and Postgraduate Studies Committee of Lingnan University, Hong Kong, China. The author is grateful for the constructive and detailed comments of Professor Leo Chan on the early draft of this article. The input of Mr. John Wong and Dr. Isaac Yue in the final stage is also much appreciated. The author is thankful for the generosity of the China People's University Press for granting permission to use the picture of Zhigong Tu as printed in their publication. 


\section{NOTES}

1. Interestingly, the ideographical meaning of this Chinese character is a person who carries a bow.

2. Since Emperor Taizong was commonly honored by the non-Chinese, frontier neighbors and states as the "Heavenly qaghan," the Tang Empire had since adopted a patrimonial approach in dealing with them. In principle, these states were not regarded as uncivilized or inadequate. Instead they were like members of a family in the Chinese empire, and love and mutual support were the central themes in this ideal world order in Asia.

3. The name of the office, "the Grand Honglu" or "the Court of State Ceremonials," was first found in historical records as early as $104 \mathrm{BC}$ during the early Han (206 BC-AD 8) dynasty, in the reign of Emperor $\mathrm{Wu}(140 \mathrm{BC}-87 \mathrm{BC})$. Such an establishment to handle foreign relations lasted until the late Qing dynasty (1644-1911).

4. See Pan Yihong 1997: 78-9 for specific examples of the appointments of Chamberlain.

5. Little has been said in the literature about the linguistic competence of the Court's staff. I suspect that they might not be entirely competent in foreign languages, since $10 \%$ of the Court's staff was interpreters. Besides, the Chamberlain was usually appointed based on his achievements in frontier military ventures, not his linguistic competence.

6. See Li Hu 1998: 315-354 and Pan Yihong 1997: 75-94.

7. Pan Yihong has a succinct understanding of the way in which standard history was composed in the Tang dynasty. She says (1997: 92), "within the Bureau of Historiography, the works based on the materials collected went through a series of stages of composition. During the Tang dynasty these were the Court Diary, Administrative Records, Daily Calendar, Veritable Records and National History, each being a digest of the material produced at the previous stage."

8. Shiji was compiled by Sima Qian (145-86 BC). The work is a history of China from the earliest times to the reign of Emperor Wu of the Han dynasty, covering a period of 3000 years.

9. Liu Boqi's observation was based on Tang Huiyao and Yuhai, the latter, an ancient book published in the Qing era. These cannot be quoted in detail because of the limited space here.

10. He Fangchuan maintains that Jia Dan has written Huanghua Sida Ji (皇華四達記) [The Routes Leading out from China in Four Directions] in which he described "the sea routes from Guangzhou to present-day Indo-China, Malaysian Peninsular, Sumatra, Srilanka, and the Gulf Bay" (2003: 26, my translation). We learn also that Jia Dan had coordinated the drawing of a map called Hainei Huayi Tu (海內華夷圖) [The Map of Barbarian States along the China Frontiers]. Another work of his was called Tufan Huanghe Lu (吐蕃黄河錄) [Register of Tibet and the Yellow River], in which he spelt out the differences in customs between the Tibetan and Chinese peoples.

11. Jiu Tangshu 138: 3782-3787.

12. Denis Twitchett remarks: "this office had an ancient and intimate connection with the work of the historians and continued to provide a variety of information for the historical record throughout the Tang period" (1992: 12).

13. According to Yuan Wenxing and Pan Yinsheng, duties of the Imperial Library were "to manage classics and illustrated works, to catalogue the imperial collections, to collate and to go through the mechanical procedures of publishing books" (1997: 305, my translation).

14. The Liang dynasty (AD 502-557) was one of the many dynasties found during a divided and chaotic period in China preceding the Sui dynasty.

15. Terms like "Honglu" (Court of Diplomatic Reception) and "Honglu Qing" (Chamberlain of the Court) are regularly found in Liangshu on p.689 and p.718. The Court must have carried out diplomatic functions similar to other dynasties within the same establishment.

16. One of the compilers of Liangshu, Yao Cha, was the historiographer of Liang dynasty. The existence of such an official post suggests the possible establishment of a historiography office in the imperial court during the Liang.

17. The tricky part is the two broken paragraphs following the portrait of the Yamato envoy, which suggests that the painting is an account of twelve country states. In fact, the two paragraphs document Yamato and Dangchang respectively. Unfortunately, the portrait of the Dangchang envoy is missing.

18. Liangshu (covered AD 502-556), completed in 636 and composed of six Annals and fifty Biographies, was compiled during the Zhenguan reign period of Emperor Taizong by Yao Cha, one of the officials in the Bureau of Historiography during the Liang dynasty, and his son, Yao Silian. 


\section{REFERENCES}

Adshead, Samuel Adrian M. (2004): Tang China. London: Palgrave MacMillan.

Drompp, Michael. R. (2005): Tang China and the Collapse of the Uighur Empire. Leiden: Netherlands, Brill's Inner Asian Library.

Fu, Xuancong and Jianguo Zhou (2000): Li Deyu Wenji Jiaojian [Collation and Annotations to the Collected Writings of Li Deyu]. Hebei: Hebei Educational Press.

He, Fangchuan (2003): Zhongwai Wenming de Jiaohui [The Meeting Points of Chinese and Non-Chinese Civilizations]. Hong Kong: City University of Hong Kong.

Jin, Weinuo (2004): Art of China from Wei to Tang Dynasty. Beijing: Chinese People's University Press.

LI, Hu (1998): Han Tang Waijiao Zhidu Shi [A History of Diplomatic Institutions of the Han and Tang Dynasties]. Lanzhou: Lanzhou University Press.

LI, Nanqiu (2002): Zhongguo Kouyishi [A Chinese History of Interpreting]. Qingdao: Qingdao Press.

Light, Kaiman (2001): Tongjian Huzhu Yinyi Shukao [A Comprehensive List of and Reference for Missing Publications]. Unpublished doctoral dissertation. Chinese University of Hong Kong.

Liu, Boqi (1974): Tangdai Zhengjiaoshi [A History of Tang Politics and Religions]. Taipei: Chung Hwa Book Company of Republic of China.

Liu, Xu (945, rpt., 1975): Jiu Tangshu [Old History of the Tang]. Beijing: Zhonghua shuju.

Lung, Rachel and Donghui Li (2005): Interpreters as Historians. Meta. 50(3): 997-1009.

Ouyang, Xiu (1060, rpt., 1975): Xin Tangshu [New History of the Tang]. Beijing: Zhonghua Shuju.

Pan, Yihong (1997): Son of Heaven and Heavenly Qaghan: Sui-Tang China and Its Neighbor. Bellingham: Western Washington University Press.

Pulleyblank, Edwin G. (1990b): The Name of the Kirghiz. Central Asiatic Journal 34(1/2): 98-108.

Pulleyblank, Edwin G. (2001): Essays on Tang and pre-Tang China. Suffolk: Ashgate Publishing.

SCHAfEr, Edward H. (1963): The Golden Peaches of Samarkand. Berkeley: University of California Press.

Twitchetт, Denis (1992): The Writing of Official History under the Tang. Cambridge: Cambridge University Press.

Wang, Pu (rpt., 1987): Tang Huiyao [Collections of Important Documents of the Tang]. Beijing: Shanghai Guji.

WEI, Zheng (636, rpt., 1973): Suishu [A History of the Sui Dynasty]. Beijing: Zhonghua Shuju.

XIE, Baocheng (1995): Suitang Wudai Shixue [Historiography of the Sui, Tang and Five Dynasties]. Xiamen: Xiamen University Press.

YAo, Cha and Silian Yao (636, rpt., 1983): Liangshu [A History of the Liang Dynasty]. Beijing: Zhonghua Shuju.

YuAn, Wenxing and Yinsheng Pan, eds (1997): Tang Liudian Quanyi [A Complete Translation of the Compendium of Administrative Law of the Six Divisions of the Bureaucracy of the Great Tang]. Lanzhou: Gansu People's Publications.

\section{APPENDICES FOR CHINESE SOURCE TEXTS}

\section{Appendix 1}

諸司應送史館事例: 蕃國朝貢 (每正遇, 臚勘問土地風俗衣服貢獻, 使道里遠近, 並其 主名字報）, 有即勘報使館, 修入國史。如史官訪, 知事有堪入史者, 雖不與前件色同, 亦任直牌索承牌之處, 即依狀勘, 並限一月內報。（Tang Huiyao 63: 606-802-3） 


\section{Appendix 2}

其外夷每有番官到京, 委鴻臚訊其人本國山川、風土, 為圖以奏焉; 副上於省。(Tang Liudian Quanyi 5: 183)

\section{Appendix 3}

高祖詔其使巨:「朕聞彼土人庶多能勇捷, 今來相見, 實副朕懷。朕視爾等如子, 爾等 宜敬朕如父。」對曰:「臣等僻處一方, 道路悠遠, 聞內國由聖人, 故來朝拜。既蒙勞 賜, 親奉聖顔, 下情不勝歡喜, 願得長為奴僕也。」(Suishu 81: 1822 [Eastern Barbarians])

\section{Appendix 4}

上令所司訪其風俗。使者言倭王以天為兄, 以日為弟, 天未明時出聽政, 跏跌坐, 日出便 停理務。(Suishu 81: 1826 [Eastern Barbarians])

\section{Appendix 5}

尋討書傳, 訪採胡人, 或有所疑即詳眾口。依其本國服飾儀形, 王及庶人, 各顯容止, 即丹青模寫。(Suishu 81: 1579 [Eastern Barbarians])

\section{Appendix 6}

會昌中, 阿熱以使者見殺, 無以通于朝, 復遣注吾合素上書言狀。行三歲至京師, 武宗 大悅, 班渤海使者上, 以其處窮遠, 能脩職貢, 詔宰相即鴻臚寺見使者, 使譯官考山川 國風。有詔以鴻臚所得繢著之。(Xin Tangshu 217: 6150)

\section{Appendix 7}

\section{進紇戛斯朝貢圖傳狀}

臣二十一日於延英面奏, 吕述等准 訪紇戛斯國邑風俗, 編為一傳。今修撰已成, 稍似 詳備。臣伏見貞觀初, 因四夷來朝, 太宗令閻立本各寫其衣服形貌, 為職貢圖。臣謹令 畫工注寫注吾合素等形狀, 列於傳前。兼臣不揆淺陃, 軦撰傳序。(Fu and Zhou 2000: 347)

\section{Appendix 8}

\section{點戛斯朝貢圖傳序}

……是龍荒君長點戛斯遣注吾合素等上表, 獻良馬二匹……謹按故相魏國公賈耽 所撰《古今四夷述》, 紇戛斯者, 本堅昆國也……其所述作, 該明古今, 乃詔太子詹事韋 宗卿、秘書少監呂述, 往泣賓館, 以展私賣, 稽合異同, 霜縷關遺。傳胡貃兒離之音, 載 山川曲折之狀……臣輯因韋宗卿、吕述所紀異聞, 繢飾以事。敢敘率服, 以冠篇首。

(Fu and Zhou 2000: 20-22)

\section{Appendix 9}

…‥莫不編名屬國, 歸質鴻臚, 荒服來賓, 遐邇同福。(Liangshu 5: 130 [Emperor Yuan]) 